
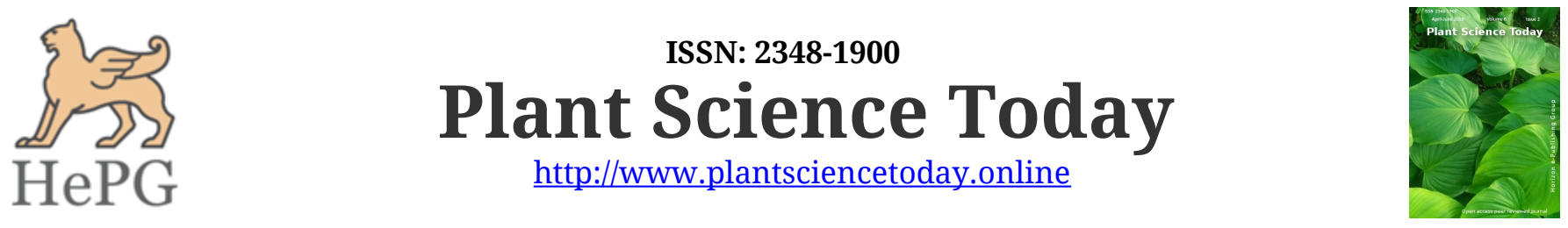
ACCESS

Research Article

\title{
Seedling Morphology of some selected members of Commelinaceae and its bearing in taxonomic studies
}

\author{
Animesh Bose $^{1^{*}} \&$ Nandadulal Paria ${ }^{2}$ \\ ${ }^{1}$ Department of Botany, Vidyasagar College, 39 Sankar Ghosh Lane, Kolkata 700006, West Bengal, India \\ ${ }^{2}$ Taxonomy \& Biosystematics Laboratory, Centre of Advanced Study, Department of Botany, University of Calcutta, 35, Ballygunge \\ Circular Road, Kolkata 700019, West Bengal, India
}

\section{Article history}

Received: 13 March 2019

Accepted: 09 April 2019

Published: 16 May 2019

\section{Publisher}

Horizon e-Publishing Group

\section{* Correspondence}

Animesh Bose

\animeshbose24@gmail.com

\begin{abstract}
Seedling morphology of eight species from four genera of the family Commelinaceae viz. Commelina appendiculata C.B. Clarke, $C$. benghalensis L., C. caroliniana Walter, $C$. paludosa Blume, Cyanotis axillaris (L.) D. Don ex Sweet, C. cristata (L.) D. Don, Murdannia nudiflora (L.) Brenan and Tradescantia spathacea Sw. are investigated using both light and scanning electron microscopy. The seedling morphological features explored include germination pattern, seed shape, surface and hilum, root system, cotyledon type, cotyledonary hyperphyll (apocole), cotyledonary hypophyll (cotyledonary sheath), hypocotyl, first leaf and subsequent leaves. All taxa studied had hypogeal and remote tubular cotyledons. However, differences in cotyledon structure (apocole, cotyledonary sheath), seed, hypocotyl, internodes, first leaf and subsequent leaves were observed. Variations of those characters were used to prepare an identification key for the investigated taxa. Commelina spp. and Murdannia nudiflora of the tribe Commelineae were found to differ from Cyanotis spp. and Tradescantia spathacea of tribe Tradescantieae in the petiolate first leaf with papillate margins on upper surface with 6celled stomata and the glabrous epicotyl. The presence of an elongated cotyledonary sheath, long apocole and extended periblast region appear to be synapomorphies for Commelina spp. and T. spathacea. The affinity of the investigated taxa as revealed through multivariate analysis supports some of the relationships inferred by pollen morphology, floral morphology and DNA (rbc-L, 5S NTS, trnL-trnF) data stated by previous authors.
\end{abstract}

Keywords: Seedling morphology; Commelinaceae; Artificial key; Identification; Phylogeny.

Citation: Bose A, Paria N. Seedling Morphology of some selected members of Commelinaceae and its bearing in taxonomic studies. Plant Science Today 2019;6(2):218-231. https://doi.org/10.14719/pst.2019.6.2.527

Copyright: (C) Bose \& Paria (2019). This is an open-access article distributed under the terms of the Creative Commons Attribution License, which permits unrestricted use, distribution and reproduction in any medium, provided the original author and source are credited (https://creativecommons.org/licenses/by/4.0/).

Indexing: Plant Science Today is covered by Scopus, CAS, AGRIS, CABI, Google Scholar, etc. Full list at http://www.plantsciencetoday.online

\section{Introduction}

The family Commelinaceae is small in comparison to other larger monocotyledonous families, like Orchidaceae and Poaceae (1). The family includes annual or perennial, erect, creeping or rarely climbing herbs and comprises 41 genera and 650 species distributed throughout the warmer parts of the world (2). The family has been extensively studied in the light of different botanical disciplines for a better understanding of the interrelationships and phylogeny of various taxa within the family. As such, Evans et al. (3,4) conducted a cladistic 

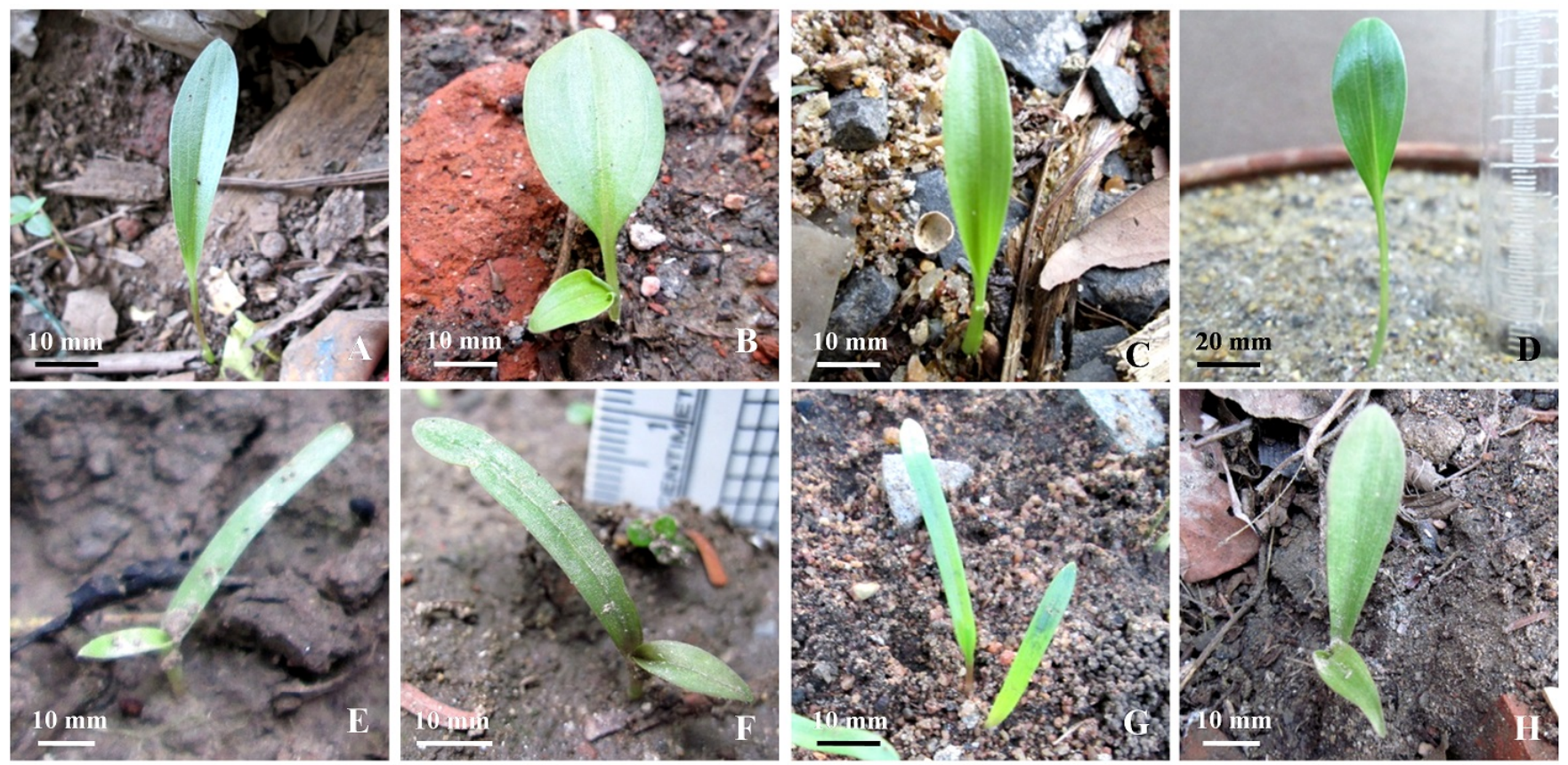

Fig. 1. Diversity of seedling first leaves, A - Commelina appendiculata showing oblanceolate first leaf; B - Commelina benghalensis with elliptic first leaf; C - Commelina caroliniana showing narrowly elliptic first leaf; D - Commelina paludosa with ellipticlanceolate first leaf; E - Cyanotis axillaris showing linear first leaf; F - Cyanotis cristata showing narrowly elliptic first leaf; $\mathbf{G}$ Murdannia nudiflora with linear first leaf; $\mathbf{H}$ - Tradescantia spathacea showing oblanceolate first leaf.

analysis of the family based upon vegetative, reproductive and rbc-L (chloroplast DNA region) data sets but it does not include the seedling features. Even Woodson (5), Brenan (6) and Faden and Hunt (7) in their classification of the Commelinaceae did not consider the seedling characters. Seedling features are morphologically and genetically stable and may play a key role in distinguishing taxa (8). Readily available characters are the germination pattern, cotyledon type, shape and surface of the seed, cotyledonary hyperphyll, cotyledonary hypophyll, hypocotyl, first leaf as well as subsequent leaves. Tillich (9) and Paria (10) reported seedling structures as a key characteristic for systematic as well as phylogenetic studies.

The earlier work reported the Commelinaceae seedlings as hypogeal with the cotyledon consisting of a long sheathing base connected to the suctorial tip by a slender, thread-like stalk (11). The seed germination and development pattern of the seedlings of Commelina virginica reported few features of seedlings (12). Some of the Commelinaceae seedlings were treated as a rare type due to a long tubular cotyledonary sheath and the thread-like hyperphyll, i.e. apocole sharply bent down and elongated like the sheath $(9,13)$. These reports revealed that the available data on the Commelinaceae seedlings are inadequate to get a clear idea on their complicated structure. As such further research in this line is necessary.

\section{Materials and Methods}

Seedling morphological characters from eight species belonging to four genera of Commelinaceae viz. Commelina appendiculata C.B. Clarke, $C$. benghalensis L., C. caroliniana Walter, $C$. paludosa Blume, Cyanotis axillaris (L.) D. Don ex Sweet, C. cristata (L.) D. Don, Murdannia nudiflora (L.) Brenan and Tradescantia spathacea Sw. occurring in natural habitats of Kolkata (India) were collected (Fig. 1) and studied in different developmental stages. These eight taxa have been considered due to availability of specimens with reference to their germination through seeds. Seeds of all these taxa were also collected from the identified adult plants and grown in the Experimental Botanic Garden of the Department of Botany, University of Calcutta. Voucher numbers, habitat and date of collection are provided in Table 1. The different developmental stages of each seedling taxon were considered. Seedlings raised in garden were compared to those collected from the field. No significant differences found between the garden raised and those from the wild collected. Ten to fifteen specimens of different developmental stages were studied for each taxon and taking from different habitats. Similar data on seedling morphology were noted in both the cases. The specimens were photographed, worked out, described and preserved in the form of herbarium sheets following the standard and modern herbarium techniques (14). The herbarium sheets are deposited in the Calcutta University Herbarium (CUH). The terminology proposed by Tillich (13) is used to describe the seedling morphological characters. 
Table 1. Voucher table for the investigated species of Commelinaceae.

\begin{tabular}{|c|c|c|c|c|}
\hline Taxa & Voucher Numbers & $\begin{array}{c}\text { Locality } \\
\text { (West Bengal, India) }\end{array}$ & Habitat & Date \\
\hline $\begin{array}{l}\text { Commelina appendiculata C. B. } \\
\text { Clarke }\end{array}$ & $\begin{array}{l}\text { Bose } 2126(\mathrm{CUH}) \\
\text { Bose } 2232(\mathrm{CUH})\end{array}$ & $\begin{array}{l}\text { Rajarhat, Kolkata } \\
\text { Ballygunge, Kolkata }\end{array}$ & $\begin{array}{l}\text { Pond side areas, Road side areas } \\
\text { Natural vegetation in Ballygunge } \\
\text { Science College }\end{array}$ & $\begin{array}{l}24 \text { Jun. } 2013 \\
14 \text { Jul. } 2013\end{array}$ \\
\hline Commelina benghalensis $\mathrm{L}$. & $\begin{array}{l}\text { Bose } 2137(\mathrm{CUH}) \\
\text { Bose } 2226(\mathrm{CUH}) \\
\text { Bose } 3379(\mathrm{CUH})\end{array}$ & $\begin{array}{l}\text { Rajarhat, Kolkata } \\
\text { Ballygunge, Kolkata } \\
\text { Salkia, Howrah }\end{array}$ & $\begin{array}{l}\text { Road side, pond side areas } \\
\text { Rail line surroundings } \\
\text { River side areas }\end{array}$ & $\begin{array}{l}24 \text { Jun. } 2013 \\
14 \text { Jul. } 2013 \\
10 \text { Apr. } 2014\end{array}$ \\
\hline Commelina caroliniana Walter & $\begin{array}{l}\text { Bose } 2115(\mathrm{CUH}) \\
\text { Bose } 2224(\mathrm{CUH}) \\
\text { Bose } 3376(\mathrm{CUH})\end{array}$ & $\begin{array}{l}\text { Rajarhat, Kolkata } \\
\text { Ballygunge, Kolkata } \\
\text { Salkia, Howrah }\end{array}$ & $\begin{array}{l}\text { Small forest areas } \\
\text { Rail line surroundings } \\
\text { River side areas }\end{array}$ & $\begin{array}{l}24 \text { Jun. } 2013 \\
14 \text { Jul. } 2013 \\
10 \text { Apr. } 2014\end{array}$ \\
\hline Commelina paludosa Blume & $\begin{array}{l}\text { Bose } 2162(\mathrm{CUH}) \\
\text { Bose } 3817(\mathrm{CUH})\end{array}$ & $\begin{array}{l}\text { Sealdah, Kolkata } \\
\text { Salt Lake, Kolkata }\end{array}$ & $\begin{array}{l}\text { Rail line surroundings } \\
\text { Natural vegetation in open land }\end{array}$ & $\begin{array}{l}\text { 02 Jul. } 2013 \\
02 \text { Apr. } 2015\end{array}$ \\
\hline $\begin{array}{l}\text { Cyanotis axillaris (L.) D. Don ex } \\
\text { Sweet }\end{array}$ & $\begin{array}{l}\text { Bose } 2130 \text { (CUH) } \\
\text { Bose } 3821 \text { (CUH) }\end{array}$ & $\begin{array}{l}\text { Rajarhat, Kolkata } \\
\text { Salt Lake, Kolkata }\end{array}$ & $\begin{array}{l}\text { Road side areas } \\
\text { Natural vegetation in open land }\end{array}$ & $\begin{array}{l}24 \text { Jun. } 2013 \\
02 \text { Apr. } 2015\end{array}$ \\
\hline Cyanotis cristata (L.) D. Don & Bose 2237 (CUH) & $\begin{array}{l}\text { Ballygunge, Kolkata } \\
\text { Dhakuria, Kolkata }\end{array}$ & $\begin{array}{l}\text { Natural vegetation in Ballygunge } \\
\text { Science College } \\
\text { Rail line surroundings }\end{array}$ & 14 Jul. 2013 \\
\hline Murdannia nudiflora (L.) Brenan & $\begin{array}{l}\text { Bose } 2123(\mathrm{CUH}) \\
\text { Bose } 3828(\mathrm{CUH})\end{array}$ & $\begin{array}{l}\text { Rajarhat, Kolkata } \\
\text { Salt Lake, Kolkata }\end{array}$ & $\begin{array}{l}\text { Road side, pond side areas } \\
\text { Natural vegetation in open land }\end{array}$ & $\begin{array}{l}24 \text { Jun. } 2013 \\
02 \text { Apr. } 2015\end{array}$ \\
\hline Tradescantia spathacea Sw. & $\begin{array}{l}\text { Bose } 2234(\mathrm{CUH}) \\
\text { Bose } 3823(\mathrm{CUH})\end{array}$ & $\begin{array}{l}\text { Ballygunge, Kolkata } \\
\text { Salt Lake, Kolkata }\end{array}$ & $\begin{array}{l}\text { Natural vegetation in Ballygunge } \\
\text { Science College } \\
\text { Natural vegetation in open land }\end{array}$ & 14 Jul. 2013 \\
\hline
\end{tabular}

For SEM studies, matured first leaf of some selected taxa were dried following Barthlott (15), Barthlott et al. (16) with slight modifications. After complete drying the sample were mounted on aluminum stubs with double adhesive tape and coated with palladium gold. Selected materials were viewed under CARL ZEISS EVO 18 scanning electron microscope in the Centre for Research in Nanoscience and Nanotechnology, University of Calcutta.

Multivariate analysis was performed for 45 characters of seedling, seed and first leaf upper surface following average linkage method with correlation coefficient distance by using Minitab 17 software (17).

With such an idea the present study aims at screening seedling morphological characters in different stages of growth and development of eight species belonging to four genera of Commelinaceae with a view to understand their taxonomic affinity.

\section{Results}

Germination and Cotyledon: The investigated seedlings reveal hypogeal and remote tubular germination pattern (Figs. 1A-H, 2A-X). According to Tillich (13) in remote germination a nonhaustorial part of the cotyledonary hyperphyll (apocole) creates some distance between the seed and the sheath. In monocots the cotyledon is usually partly inside and partly outside the seed, these terms phanerocotylar and cryptocotylar in germination are hardly applicable to their seedlings. The term tubular is due to the structure of cotyledonary sheath or coleoptile, i.e. tubular. Tubular cotyledon is divided into two parts, cotyledonary hyperphyll and cotyledonary hypophyll. Cotyledonary hyperphyll is represented by apocole and haustorium. Apocole is the elongated white-coloured, thread-like, glabrous part of the cotyledon that buries the plumule in case of the hypogeal, remote germination. Haustorium is the suctorial organ of cotyledonary hyperphyll that remains inside the testa. Cotyledonary hypophyll is represented by cotyledonary sheath, i.e. the basal, always bifacial part of a cotyledon embracing the cotyledonary node and protecting the plumule.

Apocole is attached with the cotyledonary sheath and their attachment region is varied. Three different possible attachment of apocole with the apical, basal and middle region of the cotyledonary sheath is noticed among the taxa (Figs. 3A-H, 4). Size of apocole is identical for $C$. appendiculata and $C$. benghalensis as both have 5 $15 \mathrm{~mm}$ length but apocole arises from middle region of the cotyledonary sheath in the earlier and apical region of the sheath in the later. In the other two lengths are $C$. caroliniana with $5-7 \mathrm{~mm}$ and $C$. paludosa with $5-8 \mathrm{~mm}$ but both of their apocole arises from middle region of the sheath. In C. axillaris apocole is very short, i.e. $1-2 \mathrm{~mm}$, whereas in $C$. cristata it is $2-4 \mathrm{~mm}$. M. nudiflora have identical length with $C$. cristata. These three taxa show basal region of apocole attachment with the sheath. In T. spathacea length is $8-20 \mathrm{~mm}$ and 

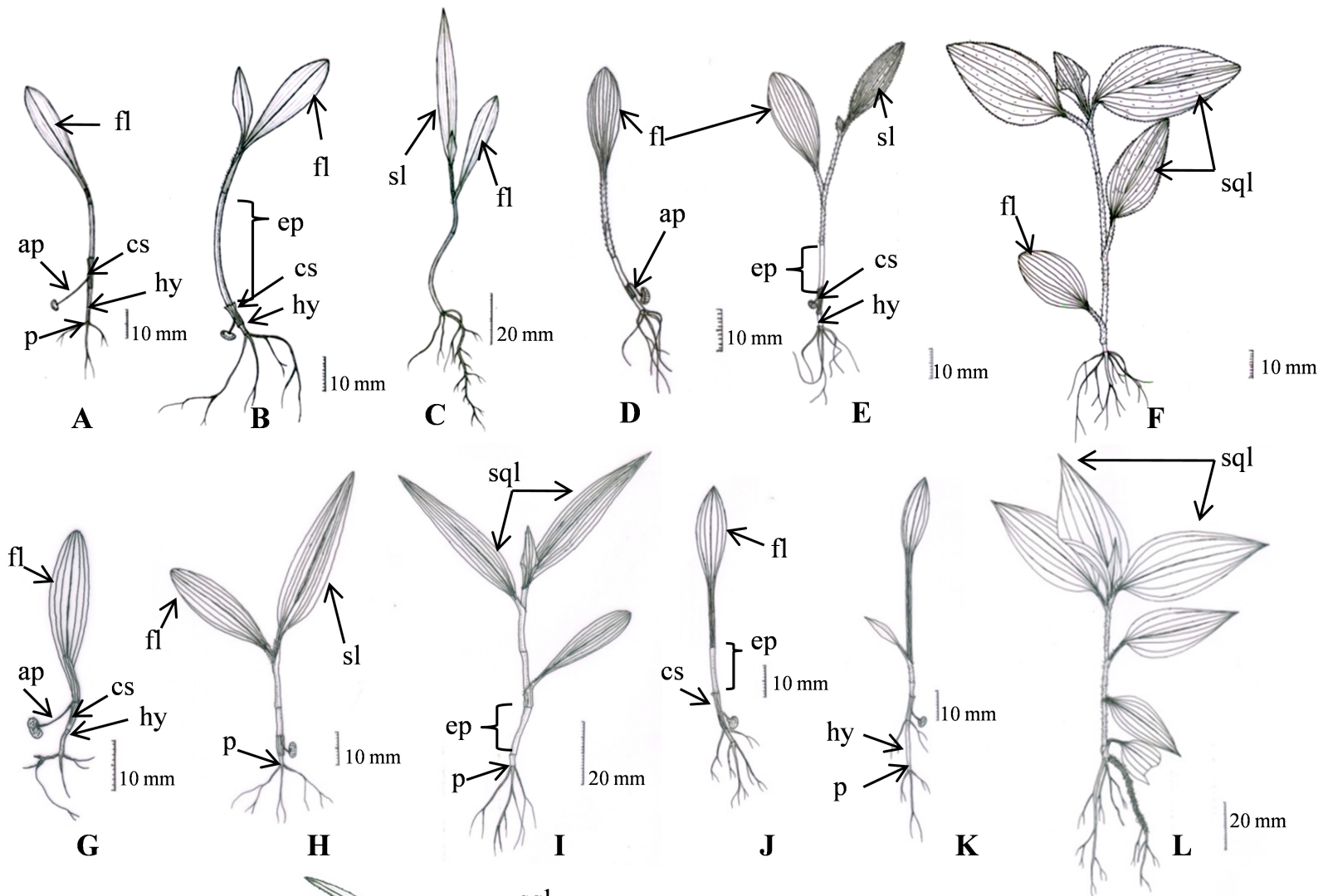

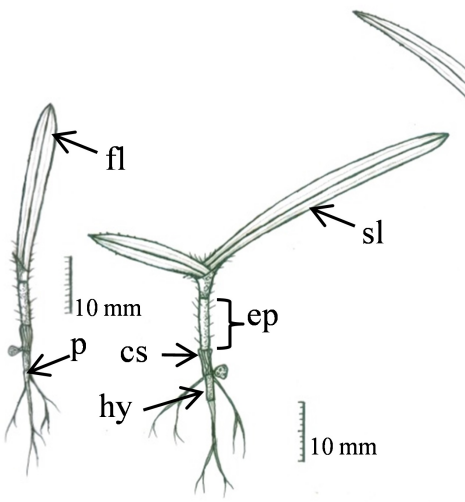

M
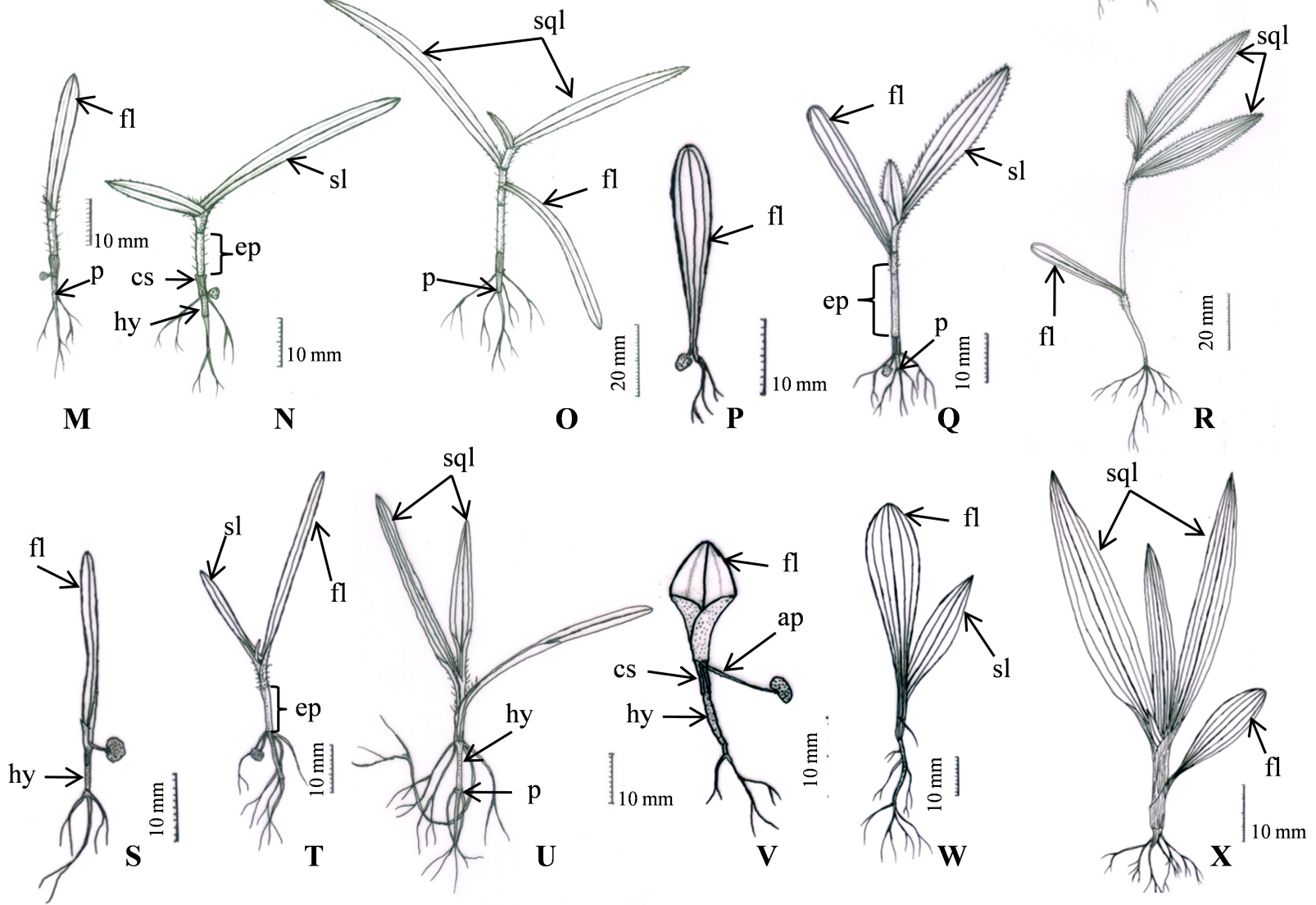

Fig. 2. Diversity of seedlings stages, A-C: Commelina appendiculata - A: first leaf stage, B: first leaf stage with initiation of second leaf, C: second leaf stage with initiation of third leaf; D-F: Commelina benghalensis - D: first leaf stage, E: second leaf stage, F: fifth leaf stage; G-I: Commelina caroliniana - G: first leaf stage, H: second leaf stage, I: third leaf stage with initiation of fourth leaf; J-L: Commelina paludosa - J: first leaf stage, K: first leaf stage with initiation of second leaf, L: sixth leaf stage; M-O: Cyanotis axillaris $\mathbf{M}$ : first leaf stage, $\mathbf{N}$ : first leaf stage with initiation of second leaf, $\mathbf{0}$ : third leaf stage with initiation of fourth leaf; P-R: Cyanotis cristata - P: first leaf stage, Q: second leaf stage with initiation of third leaf, R: third leaf stage with initiation of fourth leaf; S-U: Murdannia nudiflora - S: first leaf stage, T: second leaf stage, U: third leaf stage; V-X: Tradescantia spathacea - V: first leaf stage, W: second leaf stage, $\mathbf{X}$ : fourth leaf stage. [ap-apocole, cs- cotyledonary sheath, ep-epicotyl, fl- first leaf, hy-hypocotyl, p- periblast, slsecond leaf, sql- subsequent leaves] 

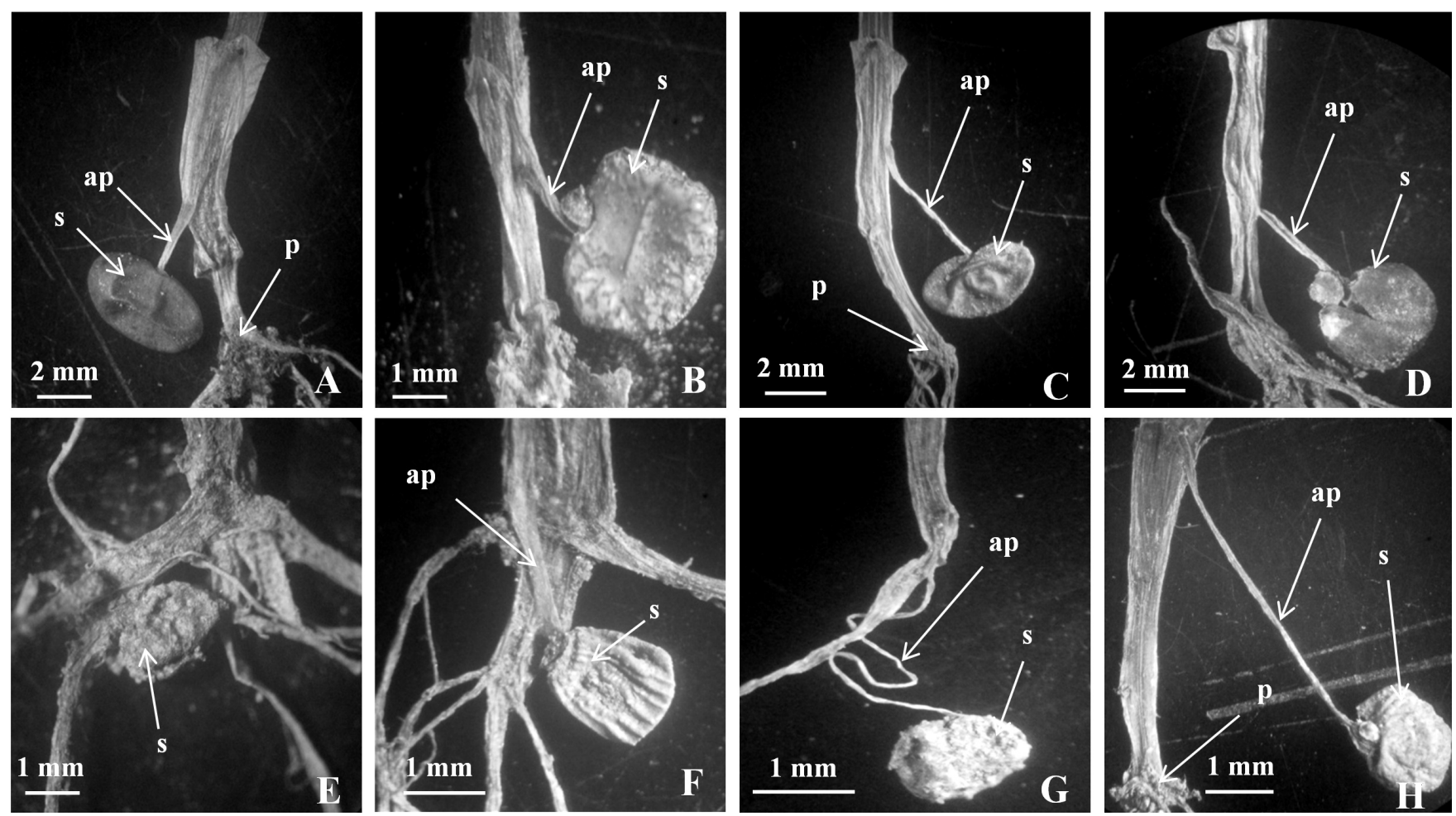

Fig. 3. Diversity of apocole attachment with cotyledonary sheath, A - middle region in Commelina appendiculata; B - apical region in Commelina benghalensis; $\mathbf{C}$ - middle region in Commelina caroliniana; $\mathbf{D}$ - middle region in Commelina paludosa; $\mathbf{E}$ - basal region in Cyanotis axillaris; F - basal region in Cyanotis cristata; $\mathbf{G}$ - basal region in Murdannia nudiflora; $\mathbf{H}$ apical region in Tradescantia spathacea. [ap: apocole, s: seed, p: periblast]

apocole arises from apical region of the cotyledonary sheath. Cotyledonary sheath is tubular, membranous, long or short, with inconspicuous venation in the investigated taxa. Length of the sheath varies between $1 \mathrm{~mm}$ in $M$. nudiflora to $8.5-12 \mathrm{~mm}$ in C. paludosa. The respective length of sheath of the other taxa mentioned in Table 2. The apical and basal regions of the sheath are noticed with some differences in width of $C$. appendiculata and $T$. spathacea. Another significant observation is the presence of constriction at the apical region of the sheath, i.e. in $C$. benghalensis, C. paludosa and T. spathacea. The tubular cotyledon is followed by the manifestation of epicotyl (first internode), first leaf and subsequent leaves.

Root and Periblast: The development of root system is mostly dependent on growing conditions. The length of the roots may be characteristic, but observation is often difficult especially of the lateral ones. The position of collet may be distinct or uncertain. The primary or tap root is soft or hard, straight or flexuous. It directly develops from the radicle. Adventitious roots are borne by the collet as seen in most of the investigated Commelinaceae. In all the taxa, tap roots are shortlived, while persistent roots are adventitious. The taproot is mostly short and appearance of adventitious roots in the early stages of germination is prominent. Adventitious roots arise from the hypocotyl apex, periblast and from the lower nodes of seedling. Both short-living tap root and persistent adventitious roots are soft, fibrous, whitish, branched. Collet region is distinguishable in the investigated taxa. Considerable swelling of the collet region finally leading to a prominent disc-like structure is known as periblast (13). Periblast region is a circular disc-like structure so its width has been studied and mentioned in Table 2 . Numerous adventitious roots normally cover the periblast region.

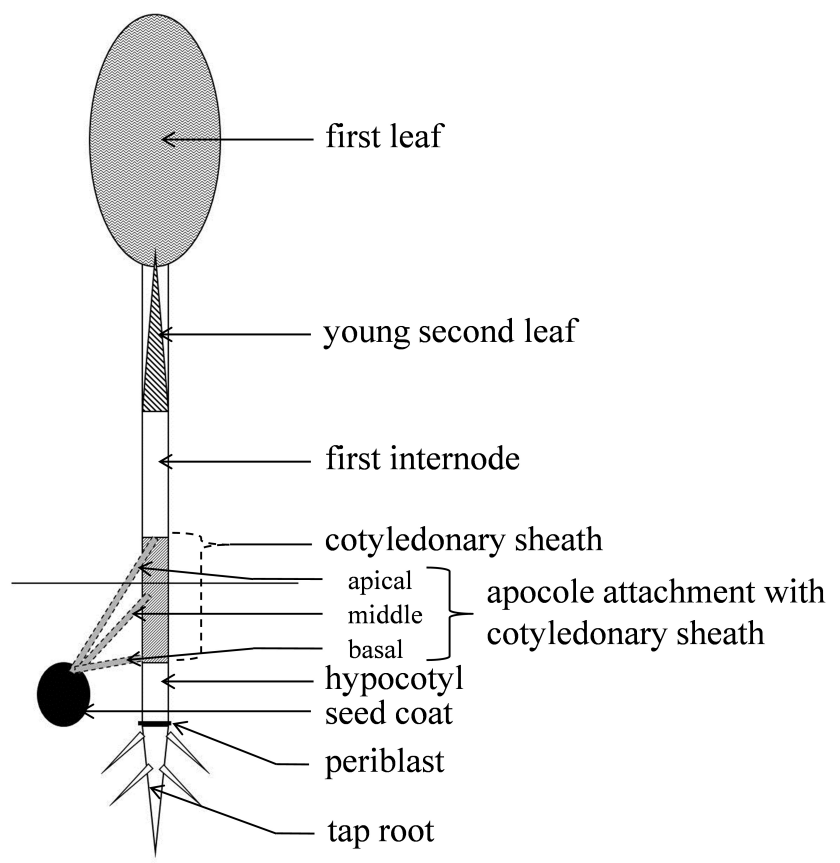

Fig. 4. Schematic diagram of Commelinaceae seedling.

Seed: In the studied seedlings the seeds remain attached with the apocole up to second or third leaf stages, its features (shape, size, surface, 

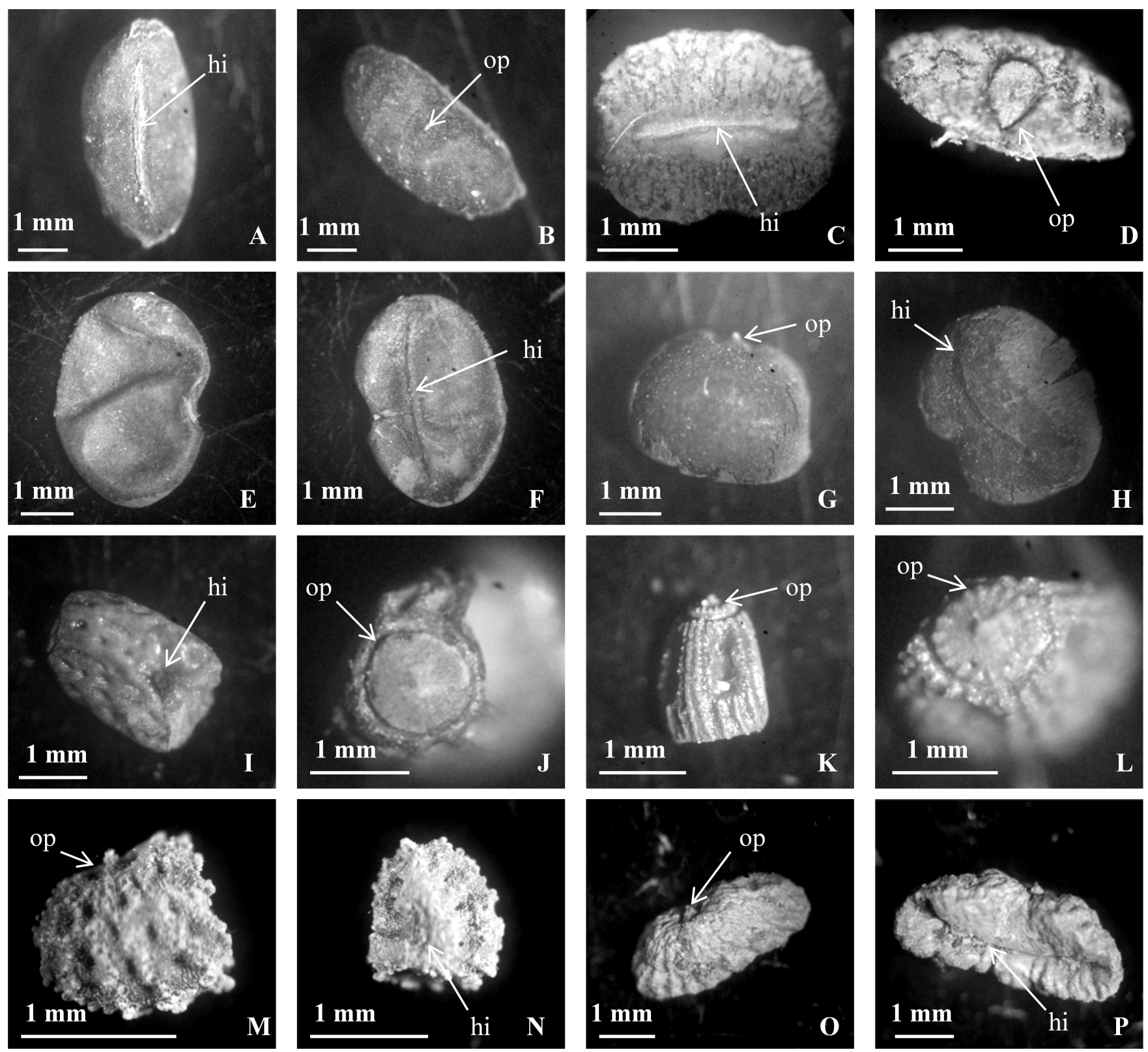

Fig. 5. Diversity of seeds, A-B: Commelina appendiculata; C-D: Commelina benghalensis; E-F: Commelina caroliniana; G-H: Commelina paludosa; I-J: Cyanotis axillaris; K-L: Cyanotis cristata; M-N: Murdannia nudiflora; O-P: Tradescantia spathacea. [hi: hilum, op: operculum]

operculum, hilum and colour) are considered under seedling characters (Fig. 5A-P; Table 3). Based on light microscopic (LM) studies, seeds of the investigated taxa reveal some promising identification characters. The four species of Commelina show four different types of seed shape. Oblong-cylindrical in C. appendiculata, oblong in $C$. benghalensis, ellipsoid in $C$. caroliniana and subglobose in $C$. paludosa. The surface pattern in $C$. benghalensis has ridges and furrows on the upper surface and a smooth lower surface, in contrast to the smooth upper and lower surfaces in the other three taxa. The two species of Cyanotis reveals oblong shaped seeds with upper and lower surfaces striate in between deep reticulations. $C$. axillaris with puncticulate surface is distinguishable from $C$. cristata having $1-4$ circular pits. Seed of $M$. nudiflora is ovoid with upper and lower surface punctuate. T. spathacea have similar shape of seed with $C$. appendiculata, i.e. oblong-cylindrical, but their surface differs. Upper and lower surface of $T$. spathacea seed is irregularly striate. An interesting observation in the seeds of $C$. appendiculata, $C$. caroliniana and $M$. nudiflora is the presence of white farinose over their surface.

The seed size alone is of little taxonomic significance. There is random size distribution of seeds in the taxa studied. The size differences between the species of a genus vary within a narrow limit (Table 3). The largest seeds are noticed in $C$. appendiculata and $C$. caroliniana with size (length $\mathrm{x}$ breadth $\mathrm{x}$ width) $3.5-5 \mathrm{~mm} \times 1.5-2$ $\mathrm{mm} \times 1.2-1.8 \mathrm{~mm}$ and $3-4.5 \mathrm{~mm} \times 2-2.8 \mathrm{~mm} \mathrm{x}$ $1.5-2 \mathrm{~mm}$ respectively. The smallest seeds are of $M$. nudiflora having size $1-1.2 \mathrm{~mm} \times 0.9-1 \mathrm{~mm} \times$ $0.5-0.6 \mathrm{~mm}$. 
Table 2. Seedling morphological data of the investigated species of Commelinaceae
Taxa Commelina
Commelina Commelina Commelina
Cyanotis
Cyanotis
Murdannia
Tradescantia appendiculata
C.B.Clarke
benghalensis $\mathrm{L}$.
caroliniana Walter paludosa Blume axillaris (L.) D.D
ex Sweet
Brenan
spathacea Sw.

(Figs. 1B, 2D-F

(Figs. 1C, 2G

$4 I-J$

(Figs. 1F, 2P-R

$3 F, 4 K-L)$

Characters

$3 A, 4 A-B)$

$4 E-F) \quad 4 G-H)$

Figs. 1G, 2S-U, 3G,

$4 M-N) \quad$ (Figs. 1H, 2V-X, 3H, 4O-P)

\begin{tabular}{|c|c|c|c|c|c|c|c|c|}
\hline Germination & hypogeal, remote & hypogeal, remote & hypogeal, remote & hypogeal, remote & hypogeal, remote & hypogeal, remote & hypogeal, remote & hypogeal, remote \\
\hline Hypocotyl & & & & & & & & \\
\hline length (mm) & $4-28$ & $9-15$ & $2-5$ & $10-18$ & $4-6$ & $4-9$ & $3-9$ & $8-28$ \\
\hline surface & glabrous & glabrous & glabrous & glabrous & glabrous & glabrous & glabrous & minutely hairy \\
\hline Periblast (mm) & $1-1.5$ & $0.8-1.5$ & $1-1.5$ & $1.5-2$ & $1.2-1.5$ & $0.5-1$ & $0.5-1.2$ & $0.8-1.5$ \\
\hline $\begin{array}{l}\text { Cotyledon } \\
\text { type }\end{array}$ & tubular & tubular & tubular & tubular & tubular & tubular & tubular & tubular \\
\hline apocole & $\begin{array}{l}5-15 \mathrm{~mm} \text {, from the } \\
\text { middle region of the } \\
\text { sheath }\end{array}$ & $\begin{array}{l}5-15 \mathrm{~mm} \text {, from the } \\
\text { apical region of the } \\
\text { sheath }\end{array}$ & $\begin{array}{l}5-7 \mathrm{~mm} \text {, from the } \\
\text { middle region of } \\
\text { sheath }\end{array}$ & $\begin{array}{l}5-8 \mathrm{~mm} \text {, from the } \\
\text { middle region of } \\
\text { sheath }\end{array}$ & $\begin{array}{l}1-2 \mathrm{~mm} \text {, from the } \\
\text { basal region of the } \\
\text { sheath }\end{array}$ & $\begin{array}{l}2-4 \mathrm{~mm} \text {, from the } \\
\text { basal region of the } \\
\text { sheath }\end{array}$ & $\begin{array}{l}2.5-4 \mathrm{~mm} \text {, from the } \\
\text { basal region of the } \\
\text { sheath }\end{array}$ & $\begin{array}{l}8-20 \mathrm{~mm} \text {, from the } \\
\text { apical region of the } \\
\text { sheath }\end{array}$ \\
\hline $\begin{array}{l}\text { cotyledonary } \\
\text { sheath }\end{array}$ & $\begin{array}{l}7-12 \mathrm{~mm} \text {, apex } \\
\text { slightly wider, no } \\
\text { constrictions at apex }\end{array}$ & $\begin{array}{l}4-10 \mathrm{~mm} \text {, apex and } \\
\text { base equal, } \\
\text { constrictions at apex }\end{array}$ & $\begin{array}{l}5-7 \mathrm{~mm} \text {, apex and } \\
\text { base equal, no } \\
\text { constrictions at apex }\end{array}$ & $\begin{array}{l}8.5-12 \mathrm{~mm} \text {, apex } \\
\text { and base equal, } \\
\text { constrictions at } \\
\text { apex }\end{array}$ & $\begin{array}{l}2.5-3 \mathrm{~mm} \text {, apex and } \\
\text { base equal, no } \\
\text { constrictions at apex }\end{array}$ & $\begin{array}{l}1.2-3 \mathrm{~mm} \text {, apex and } \\
\text { base equal, no } \\
\text { constrictions at apex }\end{array}$ & $\begin{array}{c}1 \mathrm{~mm} \text {, apex and } \\
\text { base equal, no } \\
\text { constrictions at apex }\end{array}$ & $\begin{array}{c}4-6 \mathrm{~mm} \text {, apex } \\
\text { slightly wider, } \\
\text { constrictions at } \\
\text { apex }\end{array}$ \\
\hline Internodes & $\begin{array}{l}\text { first - glabrous, } \\
\text { subsequent - hairy }\end{array}$ & $\begin{array}{l}\text { first - glabrous, } \\
\text { subsequent - hairy }\end{array}$ & glabrous & glabrous & hairy & hairy & glabrous & hairy \\
\hline $\begin{array}{l}\text { First leaf petiolate/ } \\
\text { sessile }\end{array}$ & petiolate & petiolate & petiolate & petiolate & sessile & sessile & petiolate & sessile \\
\hline blade shape & oblanceolate & obovate / elliptic & narrowly elliptic & elliptic-lanceolate & linear & $\begin{array}{c}\text { oblanceolate / } \\
\text { narrowly elliptic }\end{array}$ & linear & $\begin{array}{c}\text { oblanceolate / } \\
\text { oblanceolate-ovate }\end{array}$ \\
\hline size (mm) & $30-40 \times 7-10$ & $13-33 \times 7-16$ & $24-38 \times 6.5-11$ & $25-31 \times 7-9$ & $40-50 \times 4-5$ & $23-42 \times 2.5-4$ & $26-50 \times 2-3$ & $33-51 \times 12-15$ \\
\hline apex & obtuse & obtuse / rounded & obtuse & obtuse / rounded & acute & obtuse / rounded & narrowly acute & obtuse / rounded \\
\hline base & narrowly cuneate & cuneate & attenuate & cuneate & truncate & truncate & rounded & attenuate \\
\hline surface & glabrous & glabrous & glabrous & glabrous & glabrous & glabrous & glabrous & glabrous \\
\hline $\begin{array}{c}\text { Subsequent leaves } \\
\text { petiolate/sessile }\end{array}$ & petiolate & petiolate & petiolate & petiolate & sessile & sessile & sessile & sessile \\
\hline blade shape & $\begin{array}{l}\text { narrowly elliptic / } \\
\text { lanceolate }\end{array}$ & $\begin{array}{l}\text { ovate / lanceolate- } \\
\text { ovate }\end{array}$ & oblong-lanceolate & $\begin{array}{c}\text { lanceolate / elliptic } \\
\text { lanceolate }\end{array}$ & linear & $\begin{array}{l}\text { oblong / oblong } \\
\text { lanceolate }\end{array}$ & linear & $\begin{array}{l}\text { narrowly elliptic / } \\
\text { lanceolate }\end{array}$ \\
\hline size $(\mathrm{mm})$ & $50-65$ x 8-15 & $20-55$ x 7-23 & $46-82 \times 7.5-15$ & $40-90 \times 9-25$ & $50-70 \times 5-6$ & $44-90 \times 5-16$ & $35-65 \times 3-5$ & $94-105 \times 12-16$ \\
\hline apex & acute & acute & narrowly acute & acuminate & narrowly acute & acute & narrowly acute & narrowly acute \\
\hline base & cuneate & obtuse & cuneate & cuneate & rounded & rounded & rounded & cuneate \\
\hline surface & $\begin{array}{l}\text { lightly hairy on the } \\
\text { apical margin }\end{array}$ & Hairy & glabrous & glabrous & $\begin{array}{l}\text { lightly hairy on the } \\
\text { apical margin }\end{array}$ & hairy & glabrous & glabrous \\
\hline
\end{tabular}


Embryotega or operculum, a dehiscent cup of a seed that opens during germination is commonly found in the seeds of Commelinaceae. Shape of operculum is circular (ovate in $C$. benghalensis). Position of operculum is lateral in Commelina spp., $M$. nudiflora and $T$. spathacea, whereas in Cyanotis spp. position is terminal. Hilum is the attachment scar of the funicle. It refers only to the scar left on the seed by the stalk of the ovule. Hilum is linear and situated at the central region of the seed in Commelina spp., $M$. nudiflora and T. spathacea (in C. paludosa, hilum is slightly curved). Length of the hilum varies with the size of the seed. In Cyanotis spp. hilum is terminal, basal and punctiform. Characters of colour of seed have been utilised by different authors in describing different taxa $(18,19)$. Colour of seed in the investigated taxa is normally a mixture of grey and brown colours.

Hypocotyl: A very short tap root and adventitious roots longer than tap roots with short hypocotyl are present below the cotyledonary node. The hypocotyl is the basal portion of the ascending axis and consists of one internode only. It is situated between the cotyledonary node and the collet. Hypocotyl is a significant character as it is the primary organ of a seedling that faces the environmental consequences first. In species germinating in hypogeal manner the hypocotyl is much reduced in the embryo as well as in the seedling. Hypocotyl is mainly terete, erect (slightly curved in C. appendiculata), white (purple in $M$. nudiflora) in the investigated eight taxa. Length of hypocotyl varies between $2-5 \mathrm{~mm}$ in $C$. caroliniana to $8-28 \mathrm{~mm}$ in T. spathacea. Almost identical length of hypocotyl is noticed in $C$. appendiculata, $C$. benghalensis and C. paludosa. Cyanotis spp. and $M$. nudiflora shows shorter hypocotyl in comparison to others that varies between $3-9 \mathrm{~mm}$. Surface of hypocotyl is glabrous in Commelina spp., Cyanotis spp. and $M$. nudiflora but in $T$. spathacea surface is minutely hairy.

Internodes: Internodes are straight (sometimes curved in $C$. caroliniana), cylindrical and green. In studying internodes priority was given to first three ones. First internode is known as epicotyl. In the studied taxa it is found that epicotyl is shorter than the subsequent internodes and vice versa. In C. benghalensis, C. paludosa, C. cristata and $M$. nudiflora epicotyl is comparatively shorter then subsequent internodes. Whereas, epicotyl of $C$. appendiculata, C. caroliniana and Cyanotis axillaris is longer than the other internodes. Surface of internodes are hairy in the Cyanotis spp., $T$. spathacea and glabrous in $C$. caroliniana, $C$. paludosa and $M$. nudiflora. In $C$. appendiculata and C. benghalensis epicotyl is glabrous but subsequent internodes are hairy.

First leaf: First leaf is simple, petiolate (Commelina spp., $M$. nudiflora) or sessile (Cyanotis spp., $T$. spathacea) and sheathing. Petiole is mostly varied in C. benghalesis with $2.5-20 \mathrm{~mm}$ in length and hairy surface. In $C$. appendiculata, $C$. caroliniana and $C$. paludosa petiole is $5-8 \mathrm{~mm}, 5-7 \mathrm{~mm}$ and $15-18$ $\mathrm{mm}$, respectively with glabrous surface. In $M$. nudiflora petiole is short $2-3 \mathrm{~mm}$. The sheath is hairy and oblique in all the eight taxa but their length differs. In Commelina spp. length varies between $8-15 \mathrm{~mm}$, in Cyanotis spp. $3-5 \mathrm{~mm}$ and in M. nudiflora and T. spathacea 5-7 mm.

First leaf shape is much diversified as eight different types of shapes are noticed. And these definitely help their identification in the natural condition. In the four species of Commelina four different types of shapes are observed, $C$. appendiculata - oblanceolate (30-40 $\mathrm{mm} \times 7-10 \mathrm{~mm})$, C. benghalensis - obovate or elliptic (13-33 $\mathrm{mm} \times 7$ $16 \mathrm{~mm}), C$. caroliniana - narrowly elliptic (24-38 $\mathrm{mm} \times 6.5-11 \mathrm{~mm}$ ) and $C$. paludosa - ellipticlanceolate (25-31 $\mathrm{mm} \times 7-9 \mathrm{~mm})$. In C. axillaris (40$50 \mathrm{~mm} \times 4-5 \mathrm{~mm}$ ) and $M$. nudiflora (26-50 $\mathrm{mm} \times 2-3$ $\mathrm{mm})$ shape is linear. First leaf shape of $C$. cristata and $T$. spathacea is oblanceolate or narrowly elliptic (23-42 mm x 2.5-4 mm) and oblanceolate or oblanceolate-ovate $\quad(33-51 \quad \mathrm{~mm} \quad \mathrm{x} \quad 12-15 \quad \mathrm{~mm})$ respectively. Apex is obtuse in C. appendiculata and $C$. caroliniana; obtuse or rounded in $C$. benghalensis, $C$. paludosa, $C$. cristata and $T$. spathacea; acute in C. axillaris; narrowly acute in $M$. nudiflora. Similarly, base is cuneate in $C$. benghalensis and $C$. paludosa; narrowly cuneate in C. appendiculata; attenuate in $C$. caroliniana and $T$. spathacea; truncate in Cyanotis spp.; rounded in $M$. nudiflora. Margin of the eight different leaf types is solely entire, surface glabrous and venation pattern is exclusively parallelodromous. Colour of the first leaf on adaxial and abaxial surface is green in the investigated taxa except $T$. spathacea, where abaxial surface is purple.

Subsequent leaves: Subsequent leaves with green expanded blades after first leaf are developed. Subsequent leaves also bear significant characters as those of first leaf. Subsequent leaves in Commelinaceae are started from the second leaf stage up to the stage of the matured leaves. Subsequent leaves are petiolate $(C$. appendiculata, $C$. benghalensis, C. caroliniana, C. paludosa) or sessile (Cyanotis spp., M. nudiflora, T. spathacea), with alternate (Commelina spp., Cyanotis spp. and M. nudiflora) or spiral (T. spathacea) phyllotaxy. In Commelina spp., C. cristata and T. spathacea, subsequent leaves bear noticeable variations with the first leaf, but in $C$. axillaris and $M$. nudiflora first leaf and subsequent leaves are almost identical. In C. appendiculata shape of the leaves are narrowly elliptic to lanceolate (50-65 $\mathrm{mm} \times 8-15 \mathrm{~mm}$ ) with cuneate base, acute apex, entire margin (light hairy apical margin) and glabrous surface (Fig. 2A-C). $C$. benghalensis reveals ovate or lanceolate-ovate (20$55 \mathrm{~mm} \times 7-23 \mathrm{~mm}$ ) blade with obtuse base, acute apex, entire or wavy margin and hairy surface (Fig. 2D-F). Presence of oblong-lanceolate (46-82 $\mathrm{mm} \mathrm{x}$ 


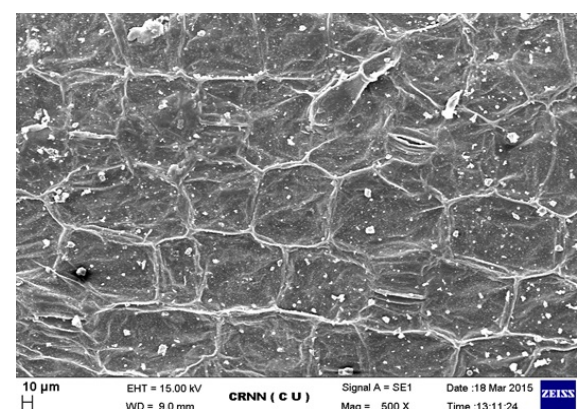

A

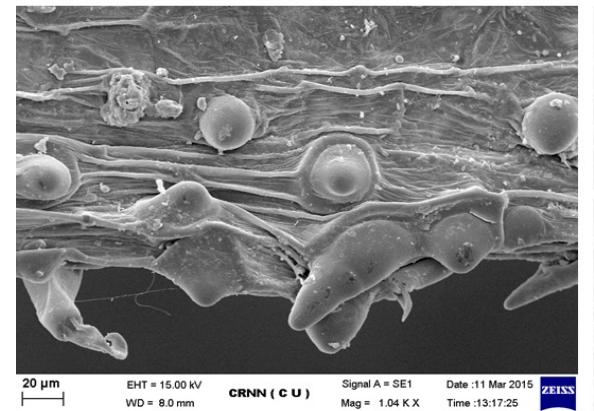

D

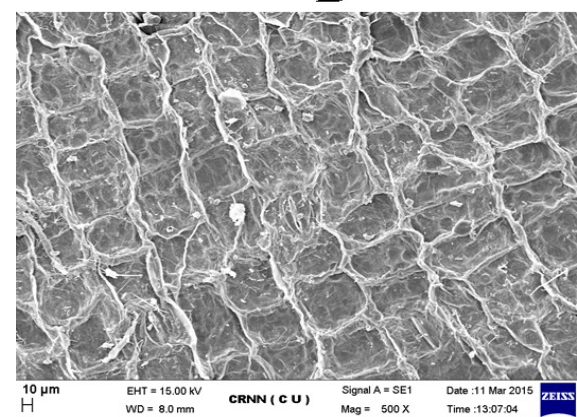

G

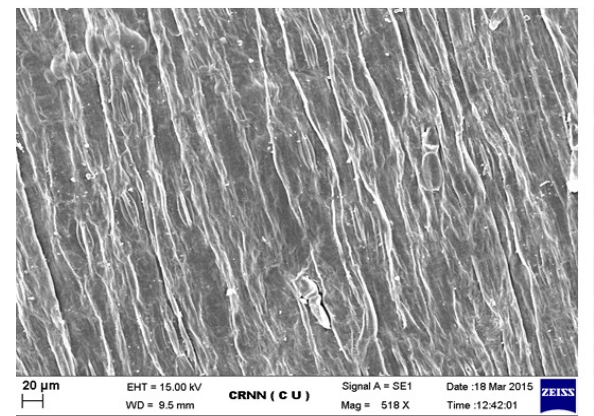

J

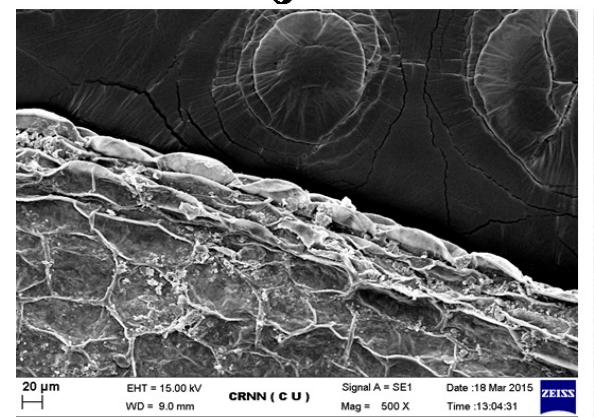

M

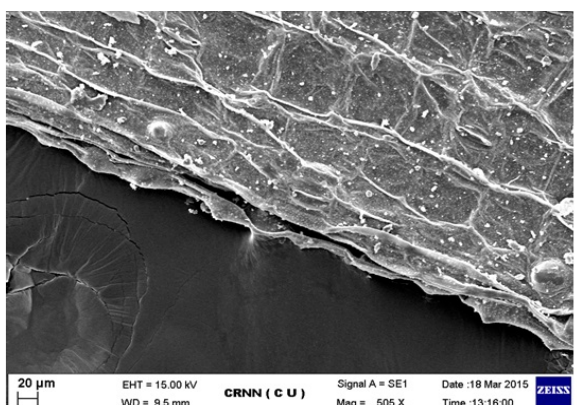

B

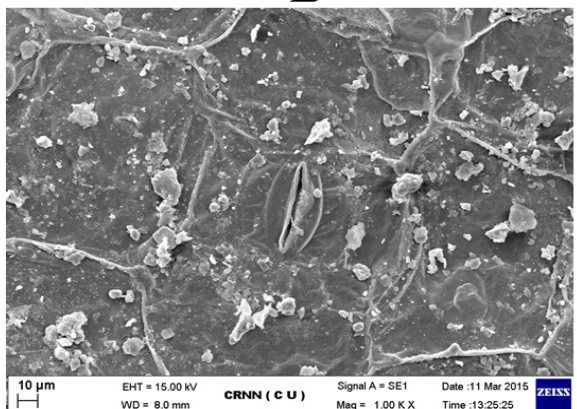

E

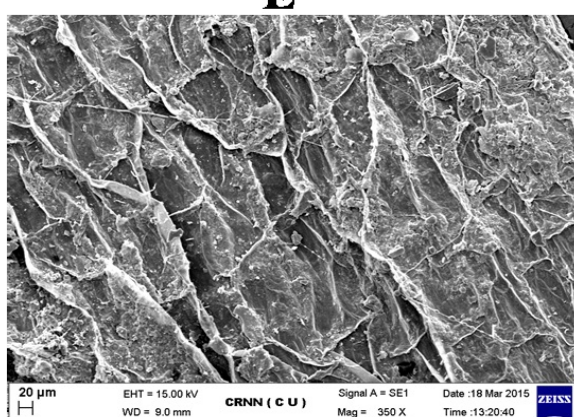

H

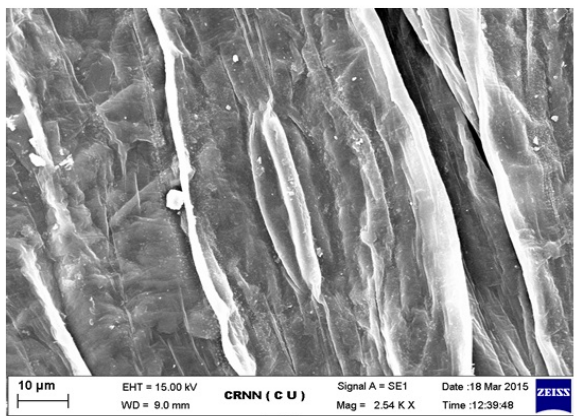

K

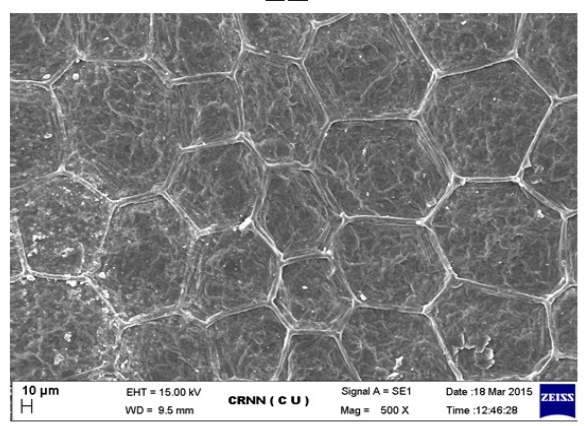

N

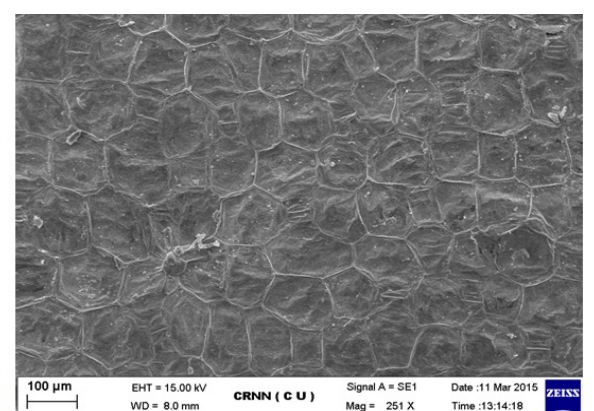

C

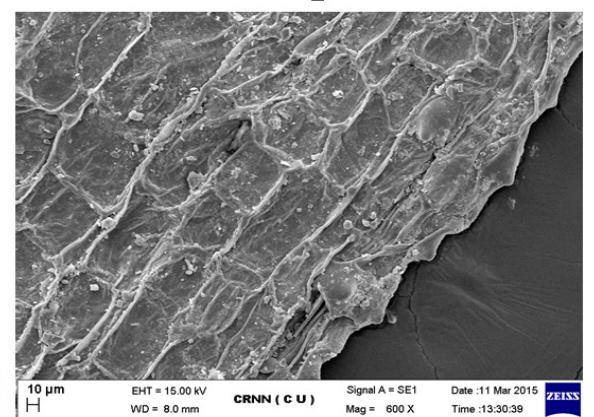

F

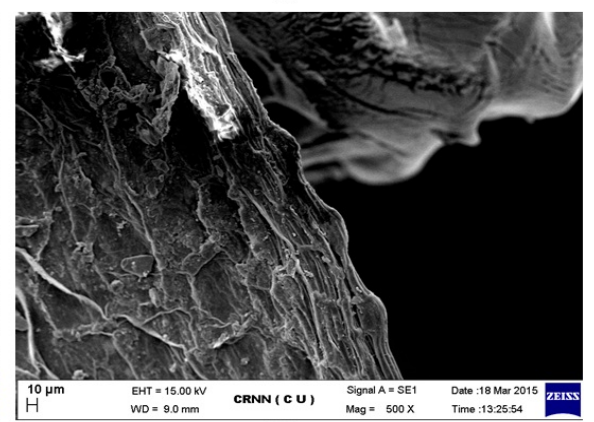

I

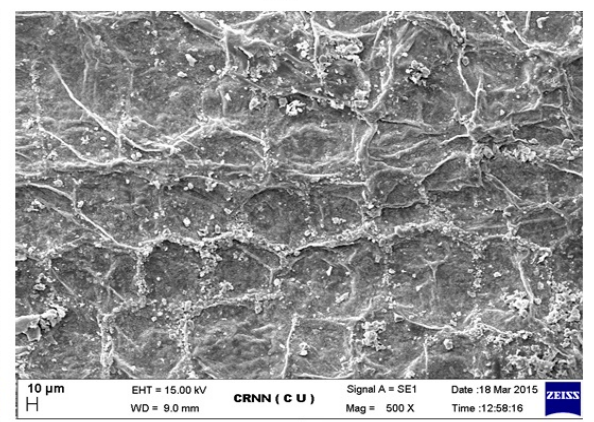

L

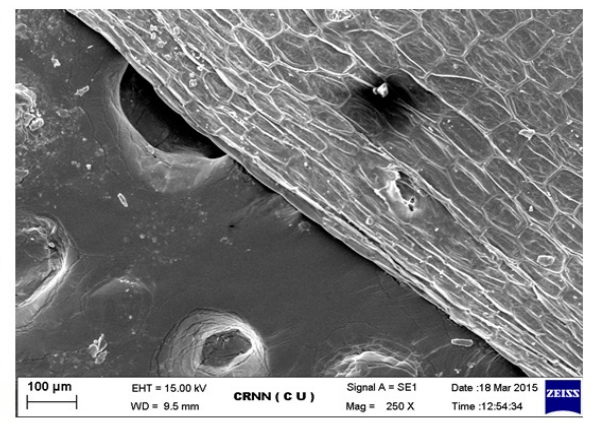

O

Fig. 6. SEM micrographs of upper epidermal surface of first leaf, A,B: Commelina appendiculata - A: hexagonal cells with 6 celled stomata ( 2 sls, 2 als, 2 ts), B: pointed papillate margin; C,D: Commelina benghalensis - C: hexagonal cells with 6 celled stomata ( 2 sls, 2 als, 2 ts), D: pointed papillate margin with 2 celled prickle hairs; E,F: Commelina caroliniana - E: polygonal cells with 6 celled stomata ( 2 sls, 2 als, 2 ts), F: pointed papillate margin; G: Commelina paludosa - rectangular cells with 6 celled stomata (2 sls, 2 als, 2 ts); H,I: Cyanotis axillaris - H: longitudinally extended rectangular cells with striae, I: margin without papillae; J,K: Cyanotis cristata - J: longitudinally extended rectangular cells with striae, and 2 celled stomata on longitudinal veins (2 ls), K: margin without papillae; L,M: Murdannia nudiflora - L: polygonal cells; M: papillate margin not pointed; N,O: Tradescantia spathacea - N: hexagonal cells, 0: margin without papillae. [sls: small lateral subsidiary cells, als: additional lateral subsidiary cells, ts: terminal subsidiary cells]. 
7.5-15 mm) blade with cuneate base, narrowly acute apex, entire margin and glabrous surface is observed in subsequent leaves of $C$. caroliniana (Fig. 2G-I). For C. paludosa blade shapes are lanceolate or elliptic-lanceolate $(40-90 \mathrm{~mm} \times 9-25$ $\mathrm{mm}$ ) having cuneate base, acuminate apex, entire margin and glabrous surface (Fig. 2J-L). For Cyanotis spp. some interesting observations are noted. In $C$. axillaris subsequent leaves are almost identical with the first leaf, except size, apex, base and surface (Fig. 2M-O). Size is larger than first leaf, i.e. $50-70 \mathrm{~mm} \times 5-6 \mathrm{~mm}$ with narrowly acute apex, rounded base and glabrous surface (light hairy apical margin). C. cristata shows noticeable variations in respect to first leaf. Its shape is oblong or oblong-lanceolate (44-90 mm x 5-16 mm), having acute apex, rounded base and hairy surface (Fig. 2P-R). M. nudiflora reveals identical features for both first leaf subsequent leaves (Fig. 2S-U). In $T$. spathacea subsequent leaves are narrowly elliptic or lanceolate $(94-105 \mathrm{~mm} \times 12-16 \mathrm{~mm}$ ) with narrowly acute apex, cuneate base and glabrous surface (Fig. 2V-X).

Upper surface of First leaf under SEM: The first leaf has been given priority for SEM study as after germination this is the primary leaf which faces the environment. From the light microscope observation, it is found that in seven of the studied eight taxa the first leaf has some character differences in contrast to the subsequent leaves. So, the first leaf characters are conservative and after facing the environment the seedling plant develops some adaptive strategies that exposes through the changes in characters of subsequent leaves. Under SEM, upper surface of first leaf of the investigated taxa reveals some significant taxonomically useful characters (Table 4).

Primarily, the cuticular deposition is comparatively thick in Cyanotis spp. and $T$. spathacea in contrast to the other taxa. The epidermal cell arrangement is in longitudinal file in six taxa, while in $C$. benghalensis and $M$. nudiflora cells are not in longitudinal file. Striae are present within the longitudinal file of cells in Cyanotis spp. Shape of epidermal cells is rectangular in $C$. paludosa, $C$. axillaris and $C$. cristata; hexagonal in $C$. appendiculata, $C$. benghalensis and T. spathacea; and polygonal in $C$. caroliniana and $M$. nudiflora. Two types of stomata depending on number of subsidiary cells are found in the investigated four genera (20). Commelina spp. and M. nudiflora have six celled stomata, i.e. with 2 small lateral, 2 additional lateral and 2 terminal subsidiary cells. Cyanotis spp. and T. spathacea reveals 4 celled stomata, i.e. with 2 terminal and 2 lateral subsidiary cells. In Cyanotis spp., stomata are present on longitudinal veins. Stomatal apparatus is comparatively large in the Commelina spp., than in the other three genera. As in the investigated taxa guard cells length is between $43-61 \mu \mathrm{m}$ in Commelina spp., $34-45 \mu \mathrm{m}$ in Cyanotis spp., $37-41$ $\mu \mathrm{m}$ in M. nudiflora and $36-38 \mu \mathrm{m}$ in T. spathacea.
Silica deposition is a regular phenomenon for the epidermal cells of Commelinaceae (20). Fine deposition of silica is found in C. appendiculata and $C$. benghalensis. In the other taxa coarsely or densely ( $M$. nudiflora) deposition of silica is noticed. Within silica some waxy substances with nonarticulate raphide canals are found in C. paludosa. Similarly, crystals and starch in addition to articulate raphide canals within silica are observed in C. axillaris. Marginal cells are longitudinally extended for all eight taxa. An interesting observation is the presence of papillae on the margin of leaves in some Commelinaceae (20). In this study, papillate margin is noticed in Commelina spp. and M. nudiflora. C. benghalensis leaf bears 2celled prickle hairs on the margin. Outside region of papillae is pointed in $C$. appendiculata, $C$. benghalensis, $C$. caroliniana and blunt in $C$. paludosa, M. nudiflora. (Fig. 6A-X).

\section{Artificial key (Valid for investigated taxa only)}

1a. Cotyledonary sheath long, more than $3 \mathrm{~mm}$; apocole arises from the apical or middle region of the sheath

1b. Cotyledonary sheath short, less than or equal to 3 $\mathrm{mm}$; apocole arises from the basal region of the sheath

2a. First leaf petiolate, stomata 6-celled, margin papillate under SEM 3

2b. First leaf sessile, stomata 4-celled, margin not papillate .................................. Tradescantia spathacea

3a. First leaf oblanceolate or obovate or elliptic, surface cells hexagonal; first internode glabrous, subsequent ones hairy

4

3b. First leaf narrowly elliptic to elliptic-lanceolate, surface cells polygonal or rectangular; internodes glabrous

5

4a. Subsequent leaves sessile, narrowly elliptic or lanceolate; first leaf margin glabrous ................. Commelina appendiculata

4b. Subsequent leaves petiolate, ovate or lanceolateovate, first leaf margin hairy

Commelina benghalensis

5a. Cotyledonary sheath with constriction at apex; hypocotyl 10 - $18 \mathrm{~mm}$ long; first leaf base cuneate . Commelina paludosa

5b. Cotyledonary sheath with no constriction at apex; hypocotyl 2 - $5 \mathrm{~mm}$ long; first leaf base attenuate Commelina caroliniana

6a. First leaf surface cells in longitudinal files, rectangular longitudinally extended, stomata 2-celled, margin not papillate

6b. First leaf surface cells not in longitudinal files, polygonal, stomata 6-celled, margin papillate Murdannia nudiflora

7a. First leaf linear, apex acute Cyanotis axillaris

7b. First leaf oblanceolate or narrowly elliptic, apex obtuse or rounded Cyanotis cristata 
Table 3. Seed morphological data of the investigated species of Commelinaceae

\begin{tabular}{|c|c|c|c|c|c|c|c|c|}
\hline Characters & $\begin{array}{l}\text { Commelina } \\
\text { appendiculata } \\
\text { C.B.Clarke } \\
\text { (Fig. } 5 \text { A, B) }\end{array}$ & $\begin{array}{l}\begin{array}{l}\text { Commelina } \\
\text { benghalensis } \mathrm{L} .\end{array} \\
(\text { Fig. } 5 C, D)\end{array}$ & $\begin{array}{l}\text { Commelina } \\
\text { caroliniana } \\
\text { Walter } \\
(\text { Fig. } 5 E, F) \\
\end{array}$ & $\begin{array}{l}\text { Commelina } \\
\text { paludosa Blume } \\
(\text { Fig. } 5 G, H)\end{array}$ & $\begin{array}{l}\text { Cyanotis axillaris } \\
\text { (L.) D. Don ex } \\
\text { Sweet } \\
\text { (Fig. 5I, J) }\end{array}$ & $\begin{array}{l}\text { Cyanotis cristata } \\
\text { (L.) D. Don } \\
\text { (Fig. } 5 K, L)\end{array}$ & $\begin{array}{l}\text { Murdannia } \\
\text { nudiflora (L.) } \\
\text { Brenan } \\
(\text { Fig. } 5 M, N) \\
\end{array}$ & $\begin{array}{l}\text { Tradescantia } \\
\text { spathacea Sw. } \\
(\text { Fig. } 50, P)\end{array}$ \\
\hline shape & oblong-cylindrical & oblong & ellipsoid & subglobose & oblong & oblong & ovoid & oblong-cylindrical \\
\hline $\operatorname{size}(1 \times b \times w) ~ m m$ & $\begin{array}{c}3.5-5 \times 1.5-2 \times 1.2- \\
1.8 \\
\end{array}$ & $\begin{array}{c}2.5-3 \times 1.5-2.2 \times \\
0.8-1.2\end{array}$ & $\begin{array}{c}3-4.5 \times 2-2.8 \times \\
1.5-2 \\
\end{array}$ & $\begin{array}{c}2.5-3 \times 2-2.5 \times 1.8 \\
-2\end{array}$ & $\begin{array}{c}1.8-2.5 \times 1.2-1.4 \\
\times 1.8-2\end{array}$ & $\begin{array}{c}1.2-1.5 \times 0.8-1 \times \\
0.6-0.8\end{array}$ & $\begin{array}{c}1-1.2 \times 0.9-1 \times 0.5 \\
-0.6\end{array}$ & $\begin{array}{c}3-4 \times 1.4-1.8 \times 1- \\
1.5 \\
\end{array}$ \\
\hline surface & $\begin{array}{l}\text { smooth with white } \\
\text { farinose }\end{array}$ & $\begin{array}{l}\text { upper-ridges- } \\
\text { furrows and lower - } \\
\text { smooth }\end{array}$ & $\begin{array}{l}\text { smooth with white } \\
\text { farinose }\end{array}$ & $\begin{array}{l}\text { smooth with white } \\
\text { farinose }\end{array}$ & $\begin{array}{c}\text { striate, } \\
\text { reticulations and } \\
\text { puncticulate }\end{array}$ & $\begin{array}{c}\text { striate, reticulate } \\
\text { with } 1-4 \text { circular } \\
\text { pits }\end{array}$ & $\begin{array}{c}\text { striate, punctuate } \\
\text { with white farinose }\end{array}$ & irregularly striate \\
\hline operculum & lateral, circular & lateral, ovate & lateral, circular & lateral, circular & terminal, circular & terminal, circular & lateral, circular & lateral, circular \\
\hline hilum (mm) & central, linear $(2.5-3)$ & $\begin{array}{c}\text { central, linear (1.1 - } \\
1.9)\end{array}$ & $\begin{array}{c}\text { central, linear (2.5 } \\
-3.1) \\
\end{array}$ & $\begin{array}{l}\text { central, slightly } \\
\text { curved (1.5- 2.1) }\end{array}$ & $\begin{array}{c}\text { terminal, basal, } \\
\text { punctiform }\end{array}$ & $\begin{array}{c}\text { terminal, basal, } \\
\text { punctiform }\end{array}$ & $\begin{array}{c}\text { central, linear }(0.2- \\
0.3),\end{array}$ & central, linear $(2.5$ - 3) \\
\hline colour & grey brown & grey brown & brown & grey & grey brown & Brown & grey brown & grey \\
\hline
\end{tabular}

Table 4. Characters of upper surface of first leaf under SEM of the investigated species of Commelinaceae

\begin{tabular}{|c|c|c|c|c|c|c|c|c|}
\hline $\begin{array}{r}\text { Taxa } \\
\text { Characters }\end{array}$ & $\begin{array}{c}\text { Commelina } \\
\text { appendiculata } \\
\text { C.B.Clarke } \\
\text { (Fig. 6A, B) }\end{array}$ & $\begin{array}{c}\begin{array}{c}\text { Commelina } \\
\text { benghalensis } \mathrm{L} .\end{array} \\
\quad(\text { Fig. } 6 C, D)\end{array}$ & $\begin{array}{c}\text { Commelina } \\
\text { caroliniana } \\
\text { Walter } \\
\text { (Fig. 6E, F) }\end{array}$ & $\begin{array}{c}\begin{array}{c}\text { Commelina } \\
\text { paludosa Blume }\end{array} \\
\text { (Fig. 6G) }\end{array}$ & $\begin{array}{l}\text { Cyanotis } \\
\text { axillaris (L.) D.Don } \\
\text { ex Sweet } \\
\text { (Fig. 6H, } I)\end{array}$ & $\begin{array}{c}\text { Cyanotis } \\
\text { cristata (L.) D. Don } \\
(\text { Fig. 6J, K) }\end{array}$ & $\begin{array}{c}\text { Murdannia } \\
\text { nudiflora (L.) } \\
\text { Brenan } \\
\text { (Fig. } 6 L, M)\end{array}$ & $\begin{array}{c}\text { Tradescantia } \\
\text { spathacea Sw. } \\
(\text { Fig. } 6 N, O)\end{array}$ \\
\hline $\begin{array}{l}\text { Cell } \\
\quad \text { arrangement }\end{array}$ & longitudinal files & $\begin{array}{l}\text { not in longitudinal } \\
\text { files }\end{array}$ & longitudinal files & longitudinal files & longitudinal files & longitudinal files & $\begin{array}{l}\text { not in longitudinal } \\
\text { files }\end{array}$ & longitudinal files \\
\hline shape & hexagonal & hexagonal & polygonal & rectangular & $\begin{array}{l}\text { rectangular } \\
\text { longitudinally } \\
\text { extended }\end{array}$ & $\begin{array}{l}\text { rectangular } \\
\text { longitudinally } \\
\text { extended }\end{array}$ & polygonal & hexagonal \\
\hline $\begin{array}{c}\text { Stomata } \\
\text { cell no. }\end{array}$ & 6 celled & 6 celled & 6 celled & 6 celled & 4 celled & 4 celled & 6 celled & 4 celled \\
\hline guard cell length & $51-53 \mu \mathrm{m}$ & $43-50 \mu \mathrm{m}$ & $58-61 \mu \mathrm{m}$ & $43-46 \mu \mathrm{m}$ & $37-45 \mu \mathrm{m}$ & $34-41 \mu \mathrm{m}$ & $37-41 \mu \mathrm{m}$ & $36-38 \mu \mathrm{m}$ \\
\hline Silica deposition & finely & finely & coarsely & coarsely & coarsely & coarsely & densely & coarsely \\
\hline Marginal cells & $\begin{array}{l}\text { longitudinally } \\
\text { extended }\end{array}$ & $\begin{array}{c}\text { longitudinally } \\
\text { extended }\end{array}$ & $\begin{array}{l}\text { longitudinally } \\
\text { extended }\end{array}$ & $\begin{array}{c}\text { longitudinally } \\
\text { extended }\end{array}$ & $\begin{array}{l}\text { longitudinally } \\
\text { extended }\end{array}$ & $\begin{array}{c}\text { longitudinally } \\
\text { extended }\end{array}$ & $\begin{array}{c}\text { longitudinally } \\
\text { extended }\end{array}$ & $\begin{array}{c}\text { longitudinally } \\
\text { extended }\end{array}$ \\
\hline Margin & papillate & $\begin{array}{c}\text { papillate, } 2 \text { celled } \\
\text { hairs }\end{array}$ & papillate & papillate & not papillate & not papillate & papillate & not papillate \\
\hline Papillae & pointed & pointed & pointed & blunt & --- & --- & blunt & --- \\
\hline
\end{tabular}




\section{Dendrogram}

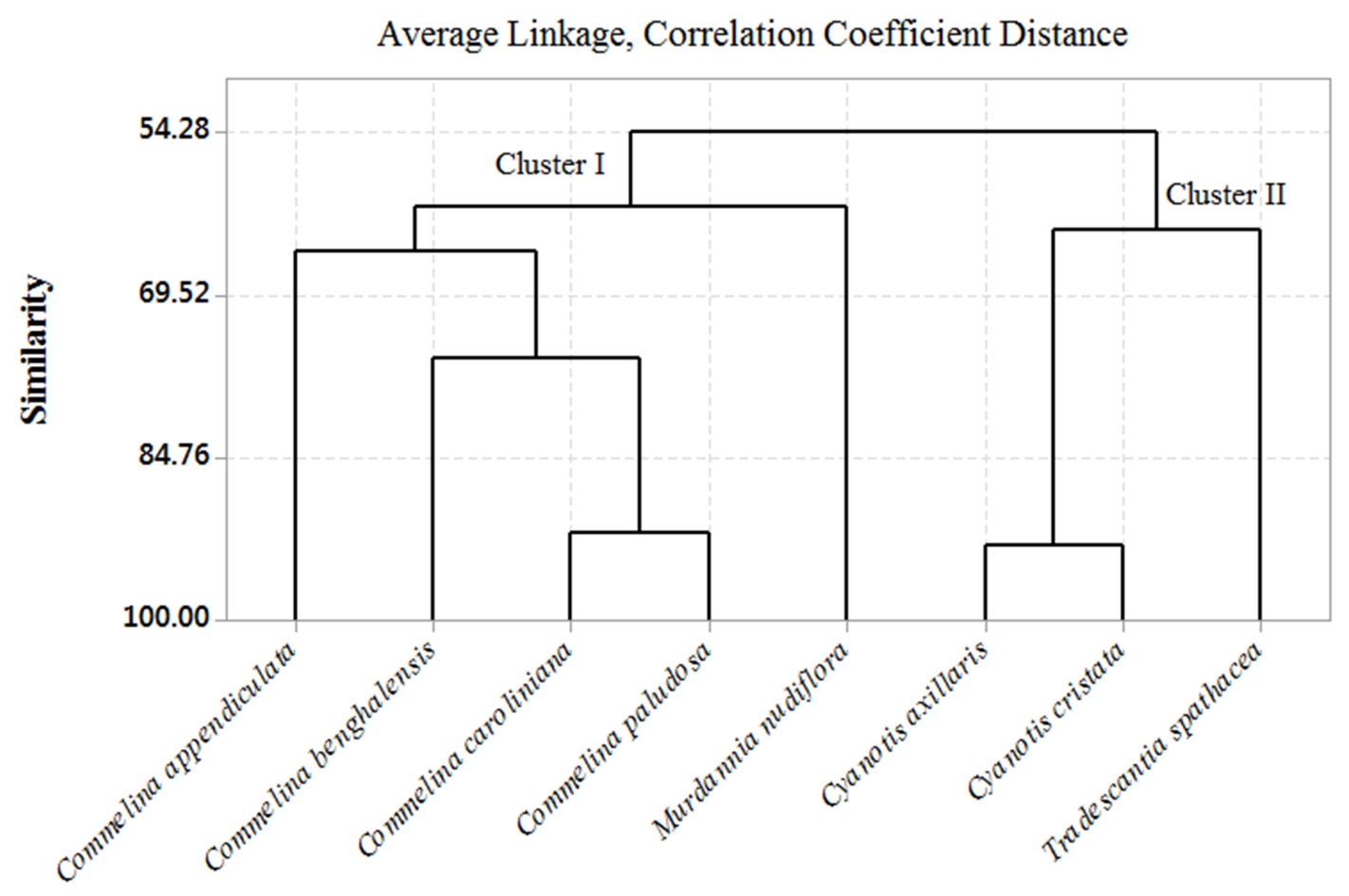

Variables

Fig. 7. Dendrogram of the eight investigated taxa (based on 45 seedling morphological characters following average linkage method with correlation coefficient distance).

Multivariate analysis: Multivariate analysis reveals a dendrogram (Fig. 7) that separates the investigated taxa into two clusters. Cluster I contains 5 taxa, of which $M$. nudiflora is sister to the four species of Commelina. Among the Commelina spp., $C$. caroliniana and $C$. paludosa are clustered together due to the similarities in seed, apocole, first leaf and subsequent leaves. $C$. benghalensis is related with $C$. caroliniana and $C$. paludosa. $C$. appendiculata is further related with the three species. $M$. nudiflora though in cotyledon structures is like the Cyanotis spp. but in the characters of hypocotyl, first leaf, subsequent leaves and upper surface of first leaf it is similar with Commelina spp. In cluster II, the two species of Cyanotis, i.e. C. axillaris and C. cristata exhibit strong relationship due to similarities in the characters of seed, hypocotyl, cotyledon, internode, first leaf, subsequent leaves and upper surface of first leaf. T. spathacea is represented as sister of Cyanotis spp. in the dendrogram.

\section{Discussion}

The present paper deals with the seedling morphology of eight species belonging to four genera of the family Commelinaceae. The seedlings are not so diversified in respect of germination pattern and cotyledon type, as hypogeal and remote germination with tubular cotyledon is the common pattern in the eight taxa. This result supported the view of Boyd (11) in having a uniform germination and seedling structure for the Commelinaceae. According to Tillich (13) remote germination is the development of seedlings at some distance from the seed. The term remote and admotive was introduced by Martius (21) to describe seedling types of palms. Tubular cotyledon is characterized by a nonhaustorial part of the cotyledonary hyperphyll (i.e. apocole), long tubular cotyledonary sheath, or a secondary tubular elongation (coleoptile) produced as a tubular protective organ for the first plumular leaves (22). The tubular cotyledon is followed by the manifestation of hypocotyl, first internode, first leaf and subsequent leaves. In addition to that seed, root and periblast have also been characterized in this investigation. Character diversity is mainly concentrated in apocole, cotyledonary sheath, internodes, first leaf and subsequent leaves, which are summarised in Table 2, 3 and 4. As revealed in the artificial key, these features can be utilised as key characters to identify the investigated Commelinaceae at seedling stage.

The objective of the investigation is not only concentrated on mere characterization of the taxa but also put some insight on their phylogenetic trends depending on seedling characters. Phylogenetic observations has been carried out based on the comments by Tillich (9), that remote-tubular cotyledon, combined with a well-developed sheath, existence of adventitious roots and absence of cataphyll represents apomorphy whereas, long-lived, freely branching primary root is the ancestral condition and 
reduction in branching, shortly elongated, small life-span primary root is rather derived. As such, the investigated eight taxa reveal hypogeal, remote germination pattern with tubular cotyledon. Remote germination is due to the cotyledon type, i.e., long thread-like apocole which keep the seed away from the seedling axis. Presence of apocole is advantageous as it helps in providing nutrient to the growing plumule. Presence of cotyledonary sheath is helpful in protecting the growing plumule, though its length may vary depending on the deepness of the seed inside the soil. Presence of apocole helps in effective assimilation of nutrient and maintaining balance of the growing seedling axis. Even an increase in the volume of root collar or collet region, i.e. periblast in Commelinaceae is also a derived state. Numerous adventitious roots and voluminous collar region, i.e. periblast not only increase the chance of successful early establishment but also function effectively in maintaining a firm contact between young seedling and substrate. In addition, cataphyll is also lacking in the investigated seedlings. However, presence of primary root and hypocotyl in all the investigated taxa represents the ancestral state. Though, primary root is small and short-lived and hypocotyl is also very short (length $2-28 \mathrm{~mm}$ ), exhibiting a trend toward advancement. So, the Commelinaceae seedlings investigated here are advanced type as a result of their noteworthy adaptive capability in an environment. Presence of long apocole (5 - 20 $\mathrm{mm})$, elongated cotyledonary sheath $(4-12 \mathrm{~mm})$ and prominent periblast region are synapomorphic for Commelina spp. and $T$. spathacea. Whereas short apocole (1 - $4 \mathrm{~mm})$, small cotyledonary sheath $(1-3 \mathrm{~mm})$ and lack of periblast are comparatively plesiomorphic for Cyanotis spp. and M. nudiflora.

The dendrogram reveals that cluster I contains Commelina spp., $M$. nudiflora of the tribe Commelineae and cluster II includes Cyanotis spp., T. spathacea of the tribe Tradescantieae, i.e. according to the established classification of Commelinaceae by Faden and Hunt (7). Further, petiolate first leaf, glabrous epicotyl, papillate margins of upper surface of first leaf with 6-celled stomata (2 small lateral, 2 additional lateral and 2 terminal subsidiary cells) are diagnostic seedling characters for the investigated members of the tribe Commelineae and sessile first leaf, hairy epicotyl, 4-celled stomata (2 terminal subsidiary cells and 2 lateral subsidiary cells) of upper surface of first leaf with lack of papillae on the margin are specific for the members of the tribe Tradescantieae.

However, the segregation of Commelina spp., M. nudiflora of Commelineae and Cyanotis spp., T. spathacea of Tradescantieae in the dendrogram can be correlated with some previous investigations. In pollen morphology, Rowley (23) and, Poole and Hunt (24) reported spinulose exine, perforate tectum and tuberculate sulcus in pollen grains of Commelina spp. and $M$. nudiflora, whereas cerebroid tectum, coarsely granulate sulcus and lack of spine on exine region is noticed in genera Cyanotis and Tradescantia. In floral morphology, Evans et al. (3) stated well developed cincinnus peduncle and sterile inner antepetalous stamens in Commelina spp. and M. nudiflora, but in Cyanotis spp. and T. spathacea cincinnus peduncle is absent and antepetalous stamens are fertile. The close proximity of Cyanotis and Tradescantia in the dendrogram also confirms the cladistic analyses by rbc-L (chloroplast DNA region) data provided by Evans et al. (4) and 5S NTS (nuclear ribosomal DNA region), trnL-trnF (chloroplast DNA region) data provided by Burns et al. (25). So, a positive scenario about the interrelationship among the eight taxa is coming out from the correlation of the dendrogram with the above mentioned other botanical disciplines and Commelinaceae classification of Faden and Hunt (7).

\section{Authors Contribution}

$\mathrm{AB}$ carried out the collection of specimens, critical analysis of different seedling parts, drawing the different stages, LM and SEM photographs and herbarium preparation part. Whereas, NDP participated in the design of the study, preparation of artificial key, statistical work, involved in drafting and gave final approval of the version of the manuscript.

\section{Acknowledgements}

The authors are grateful to the University Grants Commission Rajiv Gandhi National Fellowship Scheme for providing the necessary financial assistance in completing this investigation. Thanks are due to the Head, Department of Botany, University of Calcutta for providing infrastructural facilities.

\section{Competing Interests}

The authors have no conflict of interests.

\section{References}

1. Takhtajan AL. Flowering plants, 2nd ed. Leipzig: Springer 2009.

2. Faden RB. Commelinaceae. In: Kubitzki K. (ed.) The families and genera of vascular plants IV. Springer Verlag, Berlin 1998;p. 109-128.

3. Evans TM, Faden RB, Simpson MG, Sytsma KJ. Phylogenetic relationships in Commelinaceae: I, a cladistic analysis of morphological data. Systematic Botany 2000;25:668-691. https://10.2307/2666727

4. Evans TM, Sytsma KJ, Faden RB, Givnish TJ. Phylogenetic Relationships in the Commelinaceae: II. A 
Cladistic Analysis of rbcL Sequences and Morphology. $\begin{array}{llll}\text { Systematic Botany 2003;28 (2):270-292. } & \end{array}$ https://doi.org/10.1043/0363-6445-28.2.270

5. Woodson RE. Commentary on the North American genera of Commelinaceae. Annals of the Missouri Botanical Garden 1942;29:141-154. https://10.2307/2394315

6. Brenan JPM. The classification of Commelinaceae. Botanical Journal of the Linnean Society 1966;59:349370. https://doi.org/10.1111/j.1095-8339.1966.tb00068.x

7. Faden RB, Hunt DR. The Classification of the Commelinaceae. Taxon 1991;40 (1):19-31. https://10.2307/1222918

8. De Vogel EF. Seedlings of Dicotyledons. Centre for Agricultural Publishing and Documentation (PUDOC), Wageningen 1980.

9. Tillich HJ. Ancestral and derived character states in seedlings of monocotyledons. In: Wilson KL, Morrison DA. (eds.) Monocots: Systematics and evolution. CSIRO Publishing, Melbourne 2000;p. 221-228.

10. Paria ND. Botanical research in India in the domain of seedling morphology in relation to taxonomy. Science and Culture 2014;80 (9-10):262-270.

11. Boyd L. Monocotylous seedlings. Morphological studies in the post-seminal development of the embryo. Transactions and Proceedings of the Botanical Society Edinburgh 1932;31:5-224.

12. Bates JC. Seed Germination and Development of the Seedling in Commelina virginica. Transactions of the Kansas Academy of Science 1939;42:109-112.

13. Tillich HJ. Seedling diversity and the homologies of seedling organs in the order Poales (Monocotyledons). Annals of Botany 2007;100:1413-1429. https://doi.org/10.1093/aob/mcm238

14. Jain SK, Rao RR. A handbook of field and herbarium technique. Today and Tomorrow Publishers, New Delhi, India 1977.

15. Barthlott W. Epidermal and seed surface characters of plants: Systematic applicability and some evolutionary aspects. Nordic Journal of Botany 1981;1:345-355 https://doi.org/10.1111/j.1756-1051.1981.tb00704.X

16. Barthlott W, Neinhuis C, Cutler D, Ditsch F, Meusel I, Theisen I, Wilhelmi H. Classification and terminology of plant epicuticular waxes. Botanical Journal of the Linnean Society 1998;126(3):237-260 https://doi.org/10.1111/j.1095-8339.1998.tb02529.x

17. Minitab Inc. 2013. Minitab 17 statistical software. Coventry: Minitab Inc. Available from: http://www.minitab.com/en-US/products/minitab/defa ult.aspx.

18. Bojnansky V, Fargasova A. Atlas of seeds and fruits of Central and East-European Flora. Springer, Dordrecht, The Netherlands 2007.

19. Gandhi D, Albert S, Pandya N. Handbook on the morphology of common grasses. Apple Academic Press, Inc. Canada 2016.

20. Tomlinson PB. Commelinales-Zingiberales. In: Metcalfe CR. (ed.) Anatomy of the monocotyledons III. Clarendon Press, Oxford 1969;p. 12-63.

21. Martius CFP Von. Historia Naturalis Palmarum, Vol. 1: Palmas Generatim Tractat. München 1823.

22. Tillich HJ. Seedling diversity in Araceae and its systematic implications. Feddes Repertorium 2003;114:454-487. https://doi.org/10.1002/fedr.200311010

23. Rowley JR. The fine structure of the pollen wall in the Commelinaceae. Grana Palynologica 1959;2 (1):3-31 https://doi.org/10.1080/00173135909431974

24. Poole MM, Hunt DR. Pollen morphology and the taxonomy of the Commelinaceae: An Exploratory Survey: American Commelinaceae: VIII. Kew Bulletin 1980;34 (4):639-660. https://10.2307/4119061

25. Burns JH, Faden RB, Steppan SC. Phylogenetic Studies in the Commelinaceae Subfamily Commelinoideae Inferred from Nuclear Ribosomal and Chloroplast DNA Sequences. Systematic Botany 2011;36 (2):268-276. https://doi.org/10.1600/036364411X569471 